\title{
CREATIVE PLANNING DAN STRATEGI PENGEMBANGAN PESAN KOMUNIKASI PEMASARAN
}

\author{
Handes \\ IAIN Pontianak, Indonesia \\ Email:abyy.archie@gmail.com
}

Diterima Tangal: 1 April 2019

Selesai Tanggal 23 April 2019

\begin{abstract}
This article is focused on creative planning and marketing communication message development strategies. The results of this study found that creative planning was compiled as a reference in implementing marketing communications campaigns. In a campaign, creative planning is important to produce marketing creativity that is different, unique and interesting compared to competitors. While the message development strategy can be interpreted as a process of finding ways to influence the public or certain goals by persuading or persuasive and motivating the public to participate, so that the message is expected to create certain effects as planned according to a specific theme. The development of messages starts from a big idea to express certain intentions according to needs and benefits which are then constructed into messages that are then conveyed to the target audience. The purpose of developing messages can only be achieved if the audience understands these messages.
\end{abstract}

[Artikel ini difokuskan pada perencanaan kreatif dan strategi pengembangan pesan komunikasi pemasaran. Hasil kajian ini menemukan bahwa perencanaan kreatif disusun sebagai acuan dalam pelaksanaan kampanye komunikasi pemasaran. Dalam sebuah penyelenggaraan kampanye, perencanaan kreatif menjadi penting untuk menghasilkan kreativitas pemasaran yang berbeda, unik dan menarik dibandingkan pesaing. Sedangkan strategi pengembangan pesan dapat diartikan sebagai proses menemukan cara untuk mempengaruhi publik atau sasaran tertentu dengan cara membujuk atau persuasif dan memotivasi publik untuk berpartisipasi, sehingga pesan diharapkan dapat menciptakan efek tertentu seperti yang direncanakan sesuai dengan tema spesifik. Pengembangan pesan berawal dari suatu gagasan (big idea) untuk menyatakan maksud tertentu sesuai dengan kebutuhan dan manfaat yang kemudian di konstruksi menjadi bentuk pesan-pesan yang kemudian disampaikan kepada khalayak sasaran. Tujuan pengembangan pesan hanya dapat dicapai apabila khalayak memahami pesan-pesan tersebut].

Kata Kunci: Creative planning, Strategi Pesan, dan Komunikasi Pemasaran.

\section{PENDAHULUAN}

Untuk menghasilkan pasar yang menarik, kita perlu menempatkan perencanaan kreatif dan strategi pesan yang tepat dalam menyampaikan informasi pemasaran, pesan sangat berpengaruh dalam proses komunikasi karena pesan merupakan inti materi yang disampaikan kepada orang lain dalam bentuk gagasan baik verbal maupun nonverbal. Pesan untuk menyatakan maksud tertentu sesuai dengan kebutuhan dan manfaat bagi orang 
lain. Pesan disampaikan melalui media yang tepat, bahasa yang dimengerti, katakata yang sederhana sesuai dengan tujuan komunikasi, serta mudah dicerna oleh komunikan. Dalam perencanaan kreatif dan strategi pengembangan pesan, pesan dapat disampaikan panjang lebar, namun yang perlu diperhatikan dan diarahkan adalah tujuan akhir dari pesan itu sendiri. Strategi pesan dua aspek penting, yaitu isi pesan (the content of message) dan lambang/symbol untuk mengekspresikannya. Simbol pada komunikasi umumnya adalah bahasa yang dapat mengungkapkan pikiran dan perasaan, fakta dan opini hal yang kongkrit dan abstrak, pengalaman yang sudah lalu dan yang akan datang dan sehingga pesan dapat berkembang.

Creative planning adalah suatu perencanaan menyeluruh dan terpadu mengenai idea/gagasan dalam periklanan dan Humas (khususnya) dan komunikasi pemasaran (pada umumnya) agar pesan yang disampaikan benar-benar mampu menarik perhatian dan minat audiens dengan menampilkan keunikan, perbedaan, inovasi dalam gagasan dan eksekusi pesan yang terkandung di dalamnya. Creative planning merupakan suatu usaha untuk merencanakan segala sesuatu dengan sekreatif mungkin dan semenarik mungkin, berusaha berbeda dari orang lain/ kompetitor lain. Diharapkan dengan merancang Creative planning maka kemampuan sebuah perusahaan bisnis dapat menjual barang atau jasa sebanyakbanyaknya sehingga dapat menghasilkan keuntungan yang memuaskan. Creative planning biasanya berupa dokumen tertulis yang menjelaskan strategi kreatif perusahaan atau pengusaha atau lembaga profit oriented dalam merencanakan apa yang akan mereka lakukan dengan strategistrategi kreatif. Dengan Creative planning perusahaan dapat memanfaatkan peluang yang ada di pasar yang terdapat dilingkungan eksternal perusahaan, menjelaskan keunggulan perusahaan dari kompetitor yang lain.

Oleh karena itu terbentuk teori pesan dan kreatifitas dari serangkaian usaha perusahaan untuk merancang creative planning yang bertujuan untuk: 1) mengarahkan seluruh elemen Komunikasi Pemasaran (IMC) dari sisi kreatif idea/gagasan; 2) Menguasai sisi kreatif pesan dalam proses produksi iklan atau media kreatif (semua media); 3) Memadukan konsep kreatif dari satu jenis media ke jenis media lain; 4) Memadukan konsep kreatif iklan dengan konsep kreatif kegiatan (event) dalam Public Relations; 5) Menggagas secara kreatif berbagai event PR dan Periklanan untuk memadukan strategi pencitraan korporasi secara menyeluruh, dan; 6) Membangun merek (brand building) sebagai aset perusahaan melalui program sinergis. Hal yang paling 
pertama sebelum strategi dirumuskan adalah pengetahuan tentang produk. Informasi mengenai produk atau jasa yang akan diiklankan, termuat dalam marketing brief yang dibuat oleh klien ${ }^{1}$. Informasi tersebut biasanya meliputi: Pertama, Brand yang merupakan penjelasan apakah merek tersebut adalah merek baru atau merek yang telah lama ada di pasar; Kedua, Product knowledge yang merupakan penjelasan singkat tentang fitur yang terkandung dalam produk; Ketiga, Diferensiasi. Differensiasi adalah keunggulan yang membedakannya dengan kompetitor; Keempat, Target Audience, yaitu segmentasi yang dimaksud oleh suatu produk. Kelompok mana yang akan menjadi target market suatu produk tersebut. Mengetahui target audiens adalah memahami betul bagaimana mereka berpikir, bertindak, berperilaku. Mengamati pola pergaulan mereka. Mendengarkan bagaimana mereka berbicara. Apa yang membuat mereka tertarik untuk mendengar.

Selain creative planning dibutuhkan juga strategi komunikasi yang dilakukan oleh bagian hubungan masyarakat (public relations) atau corporate communication dalam meningkatkan hubungan baik dengan pelanggan maupun

\footnotetext{
${ }^{1}$ Agus S. Madjadikara, Bagaimana Biro Iklan Memproduksi Iklan (Jakarta: Gramedia Pustaka utama, 2004), hlm. 27.
}

calon pelanggan. Strategi komunikasi adalah kegiatan atau kampanye komunikasi yang sifatnya informasional maupun persuasif untuk membangun pemahaman dan dukungan terhadap suatu ide, gagasan, produk maupun jasa yang terencana yang dilakukan oleh suatu organisasi baik yang berorientasi laba maupun nirlaba, memiliki tujuan, rencana dan berbagai alternatif berdasarkan riset dan memiliki evaluasi ${ }^{2}$. Komunikasi pemasaran merupakan perwujudan dari konsep-konsep komunikasi. Public relations merupakan fungsi manajemen yang memusatkan perhatian pada interaksi jangka panjang antara perusahaan dengan publik untuk memperoleh goodwill, pengertian yang saling menguntungkan serta dukungan ${ }^{3}$. Komunikasi pemasaran adalah fungsi dalam manajemen yang memusatkan perhatian pada produk atau jasa untuk memenuhi keinginan dan kebutuhan konsumen. Namun, koordinasi dari dua kegiatan tersebut dapat meningkatkan efisiensi dan efektivitas pemasaran perusahaan.

Salah satu hal terpenting dalam komunikasi pemasaran adalah strategi komunikasi. Sedangkan bentuk komuni-

\footnotetext{
${ }^{2}$ Smith, D. Ronald. Strategic Planning For Public Relations. Second Edition. (London: Lawrence Erlbaum Associates Publisher, 2005), hlm. 3.

3 Smith, D. Ronald. Strategic Planning For..., hlm. 4.
} 


\section{Handes}

Creative Planning dan Strategi Pengembangan Pesan Komunikasi Pemasaran

kasi pemasaran sudah terintregrasi (Integrated marketing communication) dalam beberapa bentuk bauran komunikasi pemasaran seperti menggunakan iklan, public relations, sales promostions, personal selling, direct sell dan event. Untuk menarik perhatian khalayak, pesan komunikasi pemasaran tidak hanya sekedar berbentuk persuasif. Dibutuhkan strategi yang lebih kreatif dalam pengembangan pesan untuk menarik perhatian agar pesan itu lebih berkesan. Strategi pengembangan pesan merupakan suatu yang dimiliki manusia berupa kemauan untuk menemukan pendekatan-pendekatan, terobosan, pemikiran serta gagasan baru untuk menghadapi masalah yang paling mendesak untuk memecah masalah secara cepat dan akurat dengan caranya sendiri, untuk menghasilkan hal-hal baru serta unik yang berbeda dan lebih baik dari sebelumnya ${ }^{4}$. Untuk itu diperlukan ide-ide dan cara-cara kreatif. Kreativitas biasanya digunakan dalam beberapa industri seperti seni, musik, perfilman, periklanan, dan lain sebagainya. Menjadi kreatif berarti memiliki gagasan baru yang cenderung aneh dan berbeda dari kondisi yang sudah umum. Sehingga sebagai pemasar sosial dibutuhkan keberanian untuk mengambil resiko karena ada kalanya akan dianggap

4 Pujiyanto. Iklan Layanan Masyarakat (Yogyakarta: Penerbit ANDI, 2013), hlm. 138. bodoh (bahkan umumnya gagasan hebat awalnya dianggap gila).

Quentin Newark dalam Pujiyanto ${ }^{5}$, mengatakan ada dua hal dalam berkreativitas, yaitu: (1) Making sense, dengan berfikir simple dan jelas dalam ide dan visual, tidak membuat audiens bingung dengan karya yang rumit. (2) Creating difference, memiliki semangat untuk membuat segala sesuatunya tampak berbeda dengan yang lain, selanjutnya diharapkan dapat merangsang lahirnya karya-karya orisinil dan inovatif. Kreativitas muncul dari hasil pemikiranpemikiran seseorang, pengolahan ide yang dilakukan secara terus menerus untuk mendapatkan suatu yang baru, unik dan beda dari lainnya. Jadi pada bagian ini, kita ditantang untuk merumuskan tidak hanya menciptakan pesan komunikasi pemasaran yang persuasif dalam bauran komunikasi pemasaran yang ada.

Dalam mengembangkan suatu pesan diperlukan kemampuan antara ilmu dan seni. Pesan tidak harus dikembangkan oleh para ahli yang mampu menganalisis dan mendesain strategi pesan, tetapi harus dapat membangkitkan emosi. Jadi dalam komunikasi pemasaran, pesan memang harus menggunakan strategi pengembangan pesan agar menarik perhatian. Strategi pengembangan pesan dalam

\footnotetext{
${ }^{5}$ Pujiyanto. Iklan Layanan ..., hlm. 138.
} 


\section{Al-Hikmah: Jurnal Dakwah, Volume 13, Nomar 1, Tahun 2019}

[P. DDI-D22]

komunikasi pemasaran bisa membuat komunikator memahami seluruh perencanaan program pengembangan media. Sehingga dapat merumuskan pesanpesannya, serta memilih media-media yang cocok untuk dikembangkan dengan tipe khalayak yang ada dan kemampuan perusahaan. Dalam pengembangan pesan ini merupakan peran strategis Public Relations. Peranan pokok atau tanggung jawab Public Relations atau Humas adalah bagaimana menciptakan kepercayaan, goodwill, dan kejujuran dalam menyampaikan pesan atau informasi, serta publikasi pesan positif kepada public (khalayak) yang didukung dengan kiat dan taktik serta teknik dalam melakukan komunikasi pemasaran untuk memperoleh citra merek positif.

\section{METODE}

Artikel ini ditulis dengan pendekatan studi literatur dengan melakukan kajian pustaka dan menghimpun data dari berbagai sumber seperti jurnal, buku, dan literatur internet, serta dilanjutkan dengan mencari referensi teori yang relevan dengan permasalahan yang ditemukan. Selanjutnya, data dianalisis secara deskriptif dengan mengemukakan pendapat atau temuan yang kemudian ditinjau secara teoritis.

\section{PEMBAHASAN}

1. Creative Brief (Rangkuman Kreatif) Creative planning didefinisikan dengan jelas untuk menstimulasi tujuan yang besar yang tertuang dalam rangkuman kreatif atau creative brief yang dibuat untuk agensi dalam menciptakan iklan maupun alat komunikasi pemasaran lainnya. Rangkuman kreatif merupakan jembatan strategi dengan kreatifitas periklanan, rangkuman kreatif (Creative Brief) mewakili situasi sekarang, kompetisi, kondisi pasar dan pertimbangan media. Rangkuman itu menjadi strategi hidup dan memberikan pandangan penting bagi tim kreatif untuk menetapkan strategi dan menentukan ide penjualan utama, yang akan menjadi tema pusat kampanye periklanan. Masing-masing agensi periklanan mempunyai model rangkuman kreatif yang berbeda-beda, tergantung dari kebutuhan. Tidak ada model pemasaran yang begitu kaku sehingga anda tak dapat berubah. Tidak ada rumus pemasaran yang begitu ketat sehingga setiap perubahan dilarang. Hanya pedoman strategi tidak boleh berubah sedangkan pedoman taktisnya berupa rangkuman kreatif boleh berubah $^{6}$.

\footnotetext{
${ }^{6}$ Ian Batey, Asian Branding: A Great Way to Fly (Jakarta: Bhuana Ilmu Populer, 2003), hlm. 87.
} 
Creative brief adalah dokumen yang dipersiapkan oleh seorang eksekutif terhadap seorang klien tertentu, yang dimaksudkan baik untuk memberi inspirasi pada para copywriter maupun untuk menyalurkan upayaupaya kreatif mereka. Suatu rangkuman kreatif yang betul-betul berharga mensyaratkan bahwa dokumen tersebut dikembangkan dengan pemahaman penuh tentang kebutuhan-kebutuhan periklanan klien. Rangkuman tersebut juga mengharuskan akuisisi data riset pasar tentang kondisi persaingan serta persepsi terkini konsumen tentang merek yang diiklankan beserta saingannya.

Hal-hal yang biasanya terdapat dalam sebuah rangkuman kreatif atau creative brief $^{7}$, yaitu: Pertama, Tujuan. Aspek pertama yang paling penting sebelum merumuskan strategi periklanan adalah sebuah sasaran atau tujuan. Tujuan itu tergantung pada apa yang ingin dicapai oleh klien dalam kampanye. Misalnya, membangun kesadaran pada suatu merek, mengkomunikasikan informasi, membuat perilaku atau membangun persepsi; Kedua, Menyatakan Masalah Pemasarannya. Masalah biasanya ditemukan setelah

${ }^{7}$ Kenneth Roman, Jane Maas, dan Martin Nisenholtz, How to Advertise: Membangun Merk dan Bisnis dalam Dunia Pemasaran Baru (Jakarta: PT. Elex Media Komputindo (2005), hlm. 45. dilakukan analisis SWOT; Ketiga, Target Audience. Identifikasi audience sasaran dengan segmen yang sempit berdasarkan faktor demografi, geografis, psikologis, perilaku konsumen dan pola berpikir dan bertindak. Yang harus jadi pertimbangan adalah, semakin luas target audience maka pesan akan semakin lemah; Keempat, Ide Pesan Utama. Satu ide tunggal yang akan selalu diingat target setelah melihat iklan. Ide penjualan utama atau tema kampanye berdasarkan keuntungan kunci; Kelima, Alasan Konsumen untuk Percaya. Benefit yang berbeda dari kompetitor yang juga mengatakan hal yang sama dalam ide penjualan utama atau tema kampanyenya, atau sebuah pernyataan yang bertujuan tunggal dari sudut pandang konsumen yang menunjukkan mengapa konsumen membeli atau tidak membeli produk atau merek tersebut; Keenam, Gaya/Tone. Daya tarik yang digunakan untuk mewakili kepribadian merek. Ciri khas komunikasi yang disampaikan harus bisa membawa atau mewakili pesan periklanan, dan; Ketujuh, Dampak yang Diharapkan. Pengaruh yang diharapkan melalui periklanan dari khalayak sasaran dan bagaimana iklan ini dapat meyakinkan konsumen.

Tidak ada model pemasaran yang begitu kaku sehingga anda tak 
dapat berubah. Tidak ada rumus pemasaran yang begitu ketat sehingga setiap perubahan dilarang. Hanya pedoman strategi tidak boleh berubah sedangkan pedoman taktisnya berupa rangkuman kreatif boleh saja berubah ${ }^{8}$. Creative Brief dibuat atau diciptakan dengan tujuan memperkenalkan, membedakan, atau memosisikan produk dalam benak konsumen untuk menghadapi persaingan. Konsep harus kreatif dan simpatik agar tujuannya tercapai, yaitu menjual. Pakar periklanan Amerika Serikat asal Inggris, David Ogilvy, berkata: "It is not creative unless it sells". Akan tetapi "menjual" yang bahasa Inggrisnya "to sell" sebenarnya tidak harus selalu berarti "transaksi" yang berhubungan dengan uang. Kalau pesan dari iklan itu dapat “ditangkap" oleh sasaran, dipahami, bahkan dipercaya (the message has got across), iklan itu bisa saja dianggap berhasil (the message well sold).

\section{Merumuskan Strategi Kreatif}

Selanjutnya adalah menciptakan sesuatu secara kreatif, maksudnya adalah bagaimana cara menyampaikan sebuah pesan yang telah ditentukan dengan gaya yang berbeda sehingga dapat menarik perhatian sasaran. Gaya

${ }^{8}$ Ian Batey, Asian Branding: A Great Way..., hlm. 88. juga berfungsi sebagai pemicu ingatan, pemancing untuk membuat orang ingat kembali. Secara otomatis gaya merupakan asosiasi terhadap identitas merek $^{9}$. Menurut Durianto, dkk, $(2003)^{10}$ Ada beberapa hal yang harus diperhatikan dalam membuat perumusan kreatif: Pertama, Directed Creativity. Kreatifitas yang dibuat harus sesuai dengan what to say yang telah ditentukan. What to say ini adalah inti pesan yang ingin disampaikan kepada sasaran, tertuang dalam strategi kreatif dalam bentuk Creative Brief yang dibuat oleh tim kreatif; Kedua, Brand Name Exposure. Brand Name Exposure terdiri dari individual brand name dan company brand name. Brand Name Exposure dianggap penting karena bertujuan untuk mendapatkan brand awareness; Ketiga, Positive Uniqueness. Iklan atau alat komunikasi pemasaran lainnya yang efektif harus mampu menciptakan asosiasi yang positif. Pertama-tama iklan harus efektif, kemudian kreatif. Iklan akan menjadi sia-sia jika hanya sekedar kreatif tapi tidak efektif dan menimbulkan asosiasi yang salah

${ }^{9}$ Max Surtherland \& K. Silvester Alice, Advertising and Mind of the Consumer (Jakarta: Penerbit PPM, 2005), hlm. 77.

${ }^{10}$ Sri Widyastuti, Manajemen Komunikasi Pemasaran Terpadu (Jakarta Selatan, FEB-UP Press, 2017), hlm. 187-188. 
dibenak sasaran. Pesan yang mudah diingat dengan baik adalah yang berkaitan dengan asosiasi indra (visual), konteks emosional (cinta, kebahagiaan dan keadilan), kualitas yang menonjol atau berbeda, asosiasi yang intens, dan hal-hal yang memiliki keutamaan pribadi; Keempat, Selectivity. Berkaitan dengan pesan yang disampaikan kepada sasaran dan endoser sebagai pembawa pesan dari iklan tersebut.

Berdasarkan perumusan tersebut di atas maka sebuah pesan strategi kreatif yang disampaikan dengan gaya yang berbeda harus memiliki nilai-nilai, sebagai berikut ${ }^{11}$ : Pertama, Simple. Sebuah iklan haruslah simple. Kata simple sering diartikan sederhana, sebagai sesuatu yang dapat dimengerti dengan sekali lihat, tidak banyak elemen tapi komunikatif; Kedua, Unexpected. Pesan yang unik dan tidak terprediksi akan memiliki kemampuan untuk menempatkan diri dalam otak manusia sehingga mudah diingat; Ketiga, Persuasive. Pesan dengan daya membujuk yang kuat akan menggerakkan konsumen untuk dengan dengan brand dan tertarik untuk mencobanya; Keempat, Relevant. Ide harus tetap relevan baik dari sisi rasionalitas

\footnotetext{
11 Budiman Hakim, Lanturan Tapi Relevan, Cetakan I, (Jakarta: Penerbit Galang Press, 2005), hlm. 49-63.
}

maupun dari produknya dan harus ada korelasi dengan positioning dan personality brand; Kelima, Entertaining. Entertaining bukan berarti lucu, dalam skala yang lebih luas berarti harus mampu mempermainkan emosi konsumen. Emosi inilah yang akan mengangkat simpati konsumen terhadap produk; Keenam, Acceptable. Yang menilai sebuah strategi kreatif adalah konsumen, oleh karena itu penerimaan mereka terhadap pesan pemasaran harus diperhatikan.

Pengembangan strategi kreatif dituntun oleh tujuan dan sasaran serta di dasari faktor yang meliputi target/ sasaran pesan. Suatu bagian yang penting dalam strategi kreatif adalah bagaimana menentukan atau menemukan ide penjualan utama suatu produk $^{12}$. Penerapan strategi kreatif salah satunya dalam membuat suatu pesan iklan juga didukung dengan beberapa pendekatan yang di antaranya yaitu: Pertama, Pendekatan Generik. Pendekatan yang berorientasi pada keunggulan biaya keseluruhan dan diferensiasi. Biaya keseluruhan menonjolkan harga lebih rendah dari pada pesaing. Diferensiasi menonjolkan perbedaan yang mencolok merknya

${ }^{12}$ M. Suyanto, Strategi Perancangan Iklan Televisi Perusahaan Top Dunia (Yogyakarta: Penerbit Andi Offset, 2005), hlm. 70-84. 
dengan merk pesaing tidak secara superior; Kedua, Pendekatan Preemptive. Pendekatan ini hampir serupa dengan pendekatan generik, tetapi lebih menonjolkan superioritas produk. Strategi ini digunakan dengan cara memframing kelebihan atau keunggulan produk karena banyak produk yang fungsi atau kegunaannya sama. Pendekatan pre-emptive ini merupakan strategi yang cerdik dalam meningkatkan citra produk itu sendiri; Ketiga, Pendekatan USP. Pendekatan Unique Selling Proposition (USP) berorientasi pada keunggulan atau kelebihan produk yang tidak dimiliki oleh produk pesaing. Kelebihan tersebut juga merupakan sesuatu yang dicari atau dijadikan alasan bagi konsumen pengguna suatu produk; Keempat, Brand Image. Pada tahapan ini merupakan suatu pendekatan yang memproyeksikan suatu produk pada suatu citra (image) tertentu melalui periklanan. Gagasannya adalah agar konsumen dapat menikmati keuntungan psikologis dari sebuah produk. Pendekatan ini berorientasi pada simbol kehidupan; Kelima, Pendekatan Positioning. Gagasan umum dalam pendekatan ini adalah bagaimana menempatkan sebuah produk untuk mendapatkan posisi dalam benak konsumen. Merek yang telah memiliki posisi mapan dalam benak konsumen akan menjadi pengaruh yang kuat pada saat konsumen membutuhkan solusi; Keenam, Pendekatan Inherent Drama. Pendekatan inheren drama atau pendekatan karakteristik produk membuat konsumen membeli. Inheren drama menggunakan pendekatan yang menekankan pada pada filosofi Leo Burnett. Dia percaya bahwa iklan didasarkan pada landasan manfaat yang diperoleh konsumen. Lebih menekankan elemen dramatik yang diekspresikan pada manfaat tersebut ${ }^{13}$.

3. Pesan

Pesan merupakan seperangkat simbol verbal dan nonverbal yang mewakili perasaan,nilai, gagasan atau maksud sumber. Pesan menurut Onong Effendy (1989) ${ }^{14}$ menyatakan bahwa pesan adalah: "Suatu komponen dalam proses komunikasi berupa paduan dari pikiran dan perasaan seseorang dengan menggunakan lambang, bahasa/ lambang-lambang lainnya disampaikan kepada orang lain". Sedangkan Abdul Hanafi menjelaskan bahwa pesan itu

\footnotetext{
${ }^{13}$ Lihat juga: M. Suyanto, Aplikasi Desain Grafis Untuk Periklanan (Yogyakarta: Penerbit Andi offset, 2004), hlm. 14-15.

14 Onong Uchjana Effendy, Kamus Komunikasi (Bandung: PT. Mandar Maju, 1989), hlm. 224.
} 
adalah "produk fiktif yang nyata dihasilkan oleh sumber-encoder" ${ }^{\prime 15}$. Kalau berbicara maka "pembicaraan" itulah pesan, ketika menulis maka "tulisan" itulah yang dinamakan pesan. Menurut Stephen W. King, pesan adalah suatu bentuk yang disandi, yang secara tersirat didalamnya mengandung pengaruh sosial. Penyandian pesan (encoding), penuangan ide atau gagasan ke dalam lambang-lambang yang berarti oleh sumber agar dapat ditafsirkan (decoding) sama oleh penerima dan berikutnya agar dapat menghasilnya efek berupa perilaku yang sesuai dengan yang diharapkan. Menurut George A. Borden, isomorfik adalah kesamaan penafsiran pada perilaku yang sama dalam pikiran komunikator atau komunikan.

a. Unsur Pesan

Pesan dapat dimengerti dalam tiga unsur yaitu kode pesan, isi pesan dan wujud pesan. Pertama, kode pesan, adalah sederetan simbol yang disusun sedemikian rupa sehingga bermakna bagi orang lain. Contoh bahasa Indonesia adalah kode yang mencakup unsur bunyi, suara, huruf dan kata yang disusun sedemikian rupa sehingga mempunyai arti;

${ }^{15}$ S. M. Siahaan, Komunikasi Pemahaman dan Penerapan (Jakarta: PT. BPK Gunung Mulia, 1991), hlm. 62.
Kedua, Isi pesan, adalah bahan untuk atau materi yang dipilih yang ditentukan oleh komunikator untuk mengkomunikasikan maksudnya; Ketiga, Wujud pesan, adalah sesuatu yang membungkus inti pesan itu sendiri, komunikator memberi wujud nyata agar komunikan tertarik akan isi pesan didalamnya ${ }^{16}$.

b. Bentuk Pesan

Pesan adalah gagasan atau ide yang disampaikan oleh komunikator kepada komunikan untuk tujuan tertentu. Dalam setiap melakukan komunikasi unsur penting diantaranya adalah pesan, karena pesan disampaikan melalui media yang tepat, bahasa yang di mengerti, kata-kata yang sederhana dan sesuai dengan maksud, serta tujuan pesan itu akan disampaikan dan mudah dicerna oleh komunikan. Selain hal tersebut di atas, ada beberapa bentuk-bentuk pesan yang dapat dilihat dari segi bentuknya. Menurut Widjaja dan Wahab (1999) ${ }^{17}$ terdapat tiga bentuk-bentuk pesan yaitu: Pertama, Informatif. Yaitu untuk memberikan keterangan fakta dan data kemudian komunikan mengam-

16 S. M. Siahaan, Komunikasi Pemahaman..., hlm. 62.

17 A.W. Widjaja dan M. Arisyk Wahab, Strategi Public Relations (Jakarta: PT. Raja Grafindo Persada, 2000), hlm. 234. 
bil kesimpulan dan keputusan sendiri, dalam situasi tertentu pesan informatif tentu lebih berhasil dibandingkan persuasive; Kedua, Persuasif. Yaitu berisikan bujukan yakni membangkitkan pengertian dan kesadaran manusia bahwa apa yang kita sampaikan akan memberikan sikap berubah. Tetapi berubahnya atas kehendak sendiri. Jadi perubahan seperti ini bukan terasa dipaksakan akan tetapi diterima dengan keterbukaan dari penerima; Ketiga, Koersif. Menyampaikan pesan yang bersifat memaksa dengan menggunakan sanksi-sanksi bentuk yang terkenal dari penyampaian secara inti adalah agitasi dengan penekanan yang menumbuhkan tekanan batin dan ketakutan dikalangan publik. Koersif berbentuk perintah-perintah, instruksi untuk penyampaian suatu target.

c. Jenis Pesan

Secara umum, jenis pesan terbagi menjadi dua, yakni pesan verbal dan non-verbal. Pesan verbal adalah jenis pesan yang penyampaiannya menggunakan kata-kata, dan dapat dipahami isinya oleh penerima berdasarkan apa yang didengarnya. Sedangkan, pesan non-verbal adalah jenis pesan yang penyampaiannya tidak menggunakan kata-kata secara langsung, dan dapat dipahami isinya oleh penerima berdasarkan gerakgerik, tingkah laku, mimik wajah, atau ekspresi muka pengirim pesan. Pada pesan non-verbal mengandalkan indera penglihatan sebagai penangkap stimuli yang timbul. Dibandingkan dengan studi komunikasi verbal, studi komunikasi nonverbal sebenarnya masih relative baru. Bila bidang pertama mulai diajarkan pada zaman Yunani kuno, yakni studi tentang persuasi, khususnya pidato, studi paling awal bidang kedua mungkin baru dimulai pada tahun 1873 oleh Charles Darwin yang menulis tentang ekspresi wajah. Sejak itu, banyak orang yang mengkaji pentingnya komunikasi nonverbal demi keberhasilan komunikasi, bukan hanya ahli-ahli komunikasi, tetapi juga antropolog, psikolog, dan sosiolog. Simbolsimbol nonverbal lebih sulit ditafsirkan dari pada symbol-simbol verbal. Tidak ada satupun kamus andal yang dapat membantu penerjemah nonverbal.

Secara sederhana, pesan nonverbal adalah semua isyarat yang bukan kata-kata. Menurut Larry A. Samovar dan Richard E. Porter 


\section{Handes}

Creative Planning dan Strategi Pengembangan Pesan Komunikasi Pemasaran

(1994) dalam Mulyana $(2000)^{18}$, komunikasi nonverbal mencakup semua rangsangan (kecuali rangsangan verbal) dalam suatu setting komunikasi, yang dihasilkan oleh individu dan penggunaan lingkungan oleh individu, yang mempunyai nilai pesan potensial bagi pengirim atau penerima; jadi definisi ini mencakup perilaku yang disengaja juga tidak disengaja sebagai bagian dari peristiwa komunikasi secara keseluruhan; kita mengirim banyak pesan nonverbal tanpa menyadari bahwa pesan-pesan tersebut bermakna bagi orang lain.Kebanyakan isyarat nonverbal juga tidak universal, melainkan terikat oleh budaya, jadi dipelajari, bukan bawaan. Sedikit saja isyarat nonverbal yang merupakan bawaan. Kita semua lahir dan mengetahui bagaimana tersenyum, namun kebanyakan semua lahir dan mengetahui bagaimana tersenyum, namun kebanyakan ahli sepakat bahwa di mana, kapan, dan kepada siapa kita menujukkan emosi ini dipelajari, dan karenanya dipengaruhi oleh konteks dan budaya.
4. Strategi Pesan Kreatif

Hal yang paling sulit adalah justru hal yang paling sederhana dari proses pembuatan pesan pemasaran itu sendiri, yaitu, Pesan. Dalam Teori Ilmu Komunikasi, kepenerimaan komunikan akan pesan yang disampaikan oleh komunikator menjadi dasar penilaian akan keberhasilan suatu proses komunikasi. Untuk menentukan pesan apa yang akan disampaikan bukanlah sesuatu yang mudah. Kecenderungan client adalah ingin memasukkan sebanyak mungkin pesan. Pihak agency biasanya akan berdalih bahwa komunikasi yang bagus itu adalah yang single message. Tapi untuk menentukan single message itu gimana? Terutama untuk produk paritas dengan USP yang notabene sama dengan produk kompetitor. Dalam Teori Ilmu Komunikasi, penerimaan komunikan akan pesan yang disampaikan oleh komunikator menjadi dasar penilaian akan keberhasilan suatu proses komunikasi. Ilmu komunikasi adalah upaya yang sistematis untuk merumuskan secara tegas asas-asas penyampaian informasi serta pembentukan pendapat dan sikap $^{19}$. Jadi penetapan strategi pesan periklanan merupakan suatu keputusan

19 Onong Uchjana Effendy, Ilmu Komunikasi Teori dan Praktek (Bandung: PT. Remaja Rosdakarya, 2001), hlm. 10. 
strategis yang mampu menjamin sukses atau gagalnya suatu iklan. Hal pertama yang harus dilihat dalam iklan adalah keuntungan kunci konsumen atau ide inti sebagai jantung strategi pesan iklan. Kampanye iklan yang efektif sangat berperan besar dalam pencapaian pangsa pikiran (mind share) dan pangsa pasar (market share). Kampanye iklan yang efektif merupakan kampanye periklanan yang didasarkan pada satu tema besar saja. Tema besar ini dikenal sebagai what to say-nya sebuah iklan atau inti dari pesan yang ingin dikomunikasikan kepada audiens.

Kampanye iklan didasarkan hanya pada satu tema besar saja karena keterbatasan daya ingat manusia. Setiap hari pikiran konsumen dibombardir oleh puluhan bahkan mungkin ratusan iklan. Dengan menggunakan satu tema maka kemungkinan akan diingatnya pesan suatu iklan oleh konsumen akan jauh lebih besar daripada menggunakan beberapa tema, hal ini berlaku terutama untuk produk paritas dengan USP yang sama dengan produk kompetitor. Secara empiris hampir semua kampanye periklanan yang hanya didasarkan pada satu tema selalu sukses dijalankan, semua advertising campaign telah membuktikan keberhasilannya dengan hanya menggunakan satu tema utama saja $^{20}$. Menetapkan satu tema utama dalam membuat iklan berarti mengkomunikasikan satu hal yang kita anggap penting. Untuk menentukan tema yang tepat, diperlukan suatu analisis terhadap produk secara cermat, mendalam dan konprehensif yang terkait dengan keadaan atau fitur produk, harga, sasaran pasar, tingkat persaingan, aspek demografis, dan unsur lainnya yang terkait. Ada banyak strategi pendekatan dalam menganalisis sebuah produk untuk menemukan pesan apa (what to say) yang ingin disampaikan kepada konsumen. Pemilihan strategi yang terbaik adalah tergantung dari produk, kompetitor dan target market.

Menciptakan iklan atau pun pesan pemasaran yang kreatif tidaklah mudah, karena karya iklan merupakan hasil kolaborasi antara penulis naskah dengan pengarah seni atau antara agen dan klien ${ }^{21}$. Oleh karena itu pada tahap brainstorming (pencarian ide yang bebas) dalam sebuah kelompok semua ide ditampung untuk kemudian dinilai ulang. Biasanya saat brain storming tim kreatif menggunakan strategi tertentu dalam eksekusi kreatif. Strategi tersebut dengan cara melantur, lanturan disenga-

20 Darmadi Durianto, dkk. Invasi Pasar dengan Iklan yang Efektif (Jakarta: Gramedia, 2003), hlm. 39.

${ }^{21}$ Kenneth Roman, Jane Maas, dan Martin Nisenholtz, How to Advertise:.., hlm. 80. 


\section{Handes}

Creative Planning dan Strategi Pengembangan Pesan Komunikasi Pemasaran

ja untuk tujuan tertentu dengan tetap menjaga relevansinya, maksudnya adalah melantur sejauh-jauhnya namun merelevansikan sedekat-dekatnya ${ }^{22}$. Contoh, kreatifitas iklan adalah how to say-nya sebuah pesan periklanan atau cara yang dilakukan untuk mengkomunikasikan pesan iklan (What to say) kepada audiens. Prinsip pertama kreatifitas dalam sebuah iklan adalah bahwa kreatifitas tidak menciptakan sesuatu dari yang tidak ada. Kreatifitas membuka, memilih, kemudian mengatur kembali, menggabungkan, menghasilkan fakta, keahlian dan ide yang sudah ada sebelumnya. Dalam arti lain bahwa kreatifitas adalah penggabungan ide-ide yang telah ada untuk menciptakan sesuatu yang baru ${ }^{23}$.

\section{Strategi pengembangan Pesan}

Dalam perkembangan bisnis modern, manajemen perencanaan pesan menjadi faktor penting untuk meyakinkan khalayak. Empat poin pokok dalam perencanaan pesan yaitu; (1) Bagaimana menggunakan hasil analisis khalayak/ calon penerima gagasan untuk perenca-

${ }^{22}$ Hakim, "Memposisikan Produk dengan Membedakan Diri”, 2005 dalam: https://www.coursehero.com/file/pi43omj/2Memposisikan-Bertujuan-untuk-memposisikanproduk-dengan-membedakan-diri/

${ }^{23}$ Roman, Kenerth. Jane Maas., \& Martin Nisenholtz. (2005). How to Advertise: Membangun Merek dan Bisnis dalam Dunia Pemasaran Baru. Jakarta: PT. Elex Media Komputindo, h. 82 naan komunikasi (2) Mengembangkan gagasan dan pokok utama dari gagasan yang akan disampaikan, (3) Menyusun sketsa pesan, dan (4) Mempersiapkan umpan balik kegiatan komunikasi.

Komunikasi dalam kehidupan manusia terasa sangat penting, karena dengan komunikasi dapat menjembatani segala bentuk ide yang akan disampaikan kepada seseorang. Dalam setiap melakukan komunikasi unsur penting diantaranya adalah pesan, karena pesan disampaikan melalui media yang tepat, bahasa yang dimengerti, kata-kata yang sederhana dan sesuai dengan maksud, serta tujuan pesan itu akan disampaikan dan mudah dicerna oleh komunikan. Pesan adalah inti utama komunikasi. Tanpa pesan, tidak terjadi adanya komunikasi. Karena pesan termasuk salah satu unsure penting dalam komunikasi.

Syarat gagasan utama yang dibuat untuk perencanaan komunikasi harus ringkas, langsung pada pokok persoalan, dan memperlihatkan hasil yang akan diperoleh bila kegiatan dilakukan. Selanjutnya pokok utama merupakan tulang punggung pesan yang merencanakan garis besar subdivisi utama. Syarat pokok dari sebuah pesan, harus menyokong, menggambarkan, atau mendeskripsikan gagasan utama dengan bahasa yang ringkas dan jelas 


\section{Al-Hikmah: Jurnal Dakwah, Volume 13, Nomar 1, Tahun 2019}

[P. 0DI-022]

agar khalayak mampu mencerna isi pesan yang disajikan. Mengembangkan suatu pesan memang harus menarik perhatian. Proses dan teknik pembuatan pesan-pesan tidak dapat dibuat begitu saja dengan cepat/spontan. Pekerjaan membuat pesan agar menarik dapat disebut sebagai "pekerjaan kreatif”.

a. Big Idea

Ketika menentukan campaign project, kita harus mempertimbangkan beberapa hal. Pertama: objective, kedua: insight, dan ketiga: big idea. Ketiganya sangat penting dan saling berhubungan satu sama lain. Mendapatkan ide untuk sebuah kampanye pemasaran memang tidak selalu mudah. Kadang ide begitu saja muncul dalam satu menit, kadang perlu berhari-hari. Akan sangat bermanfaat bila dalam mengembangkan sebuah konsep kreatif, Kita mengadakan brain storming session (pertemuan sumbang saran) dulu dengan tim kreatif Kita. Beradu argument dalam proses penciptaan suatu gagasan kreatif sangat perlu agar gagasan itu lebih teruji, lebih baik, dan yang penting bisa menjual. Dengan satu ide besar pula, audiens akan lebih mudah mengingat produk. Dengan ide yang ber beda masing- masing produk juga dilihat masyarakat dalam hal yang berbeda pula. Oleh karena itu, klien dan strategic planner harus bisa menyimpulkan unique selling point apa yang dimiliki produk yang mampu membuatnya berbeda dengan produk lain sehingga bisa diterjemahkan dalam ide besar yang solid. Bigidea ini yang melingkupi objective yang akan dijalankan nantinya (Dru: 83). Jean-Marie Dru dalam bukunya, How Disruption Brought Order, menyebutnya sebagai "the idea behind the idea". Ide yang bagus harus bisa diterjemahkan dalam semua media, baik itu cetak, radio, tv, sampai billboard dan media digital ${ }^{24}$.Namun jangan lupa, kita membuat iklan bukan untuk kita sendiri melainkan untuk orang lain, yaitu khalayak sasaran produk kita. Karena itu, konsep kreatif sedapat mungkin harus diuji oleh orang-orang di luar penciptanya.

Kunci keberhasilan komunikasi pemasaran adalah pada adanya "big idea". Untuk mendapatkan big

24 Jean-Marie Dru, How Disruption Brought Order, The Story of a Winning Strategy in the World of Advertising, (USA: Palgrave Macmillan, 2007). Dikutip dari Dian Kurniasari. (2013). "As Big as Idea", dalam: https://www.kompasiana.com/dian_kur/552a42f8f1 7e61b971d623b4/as-big-as-idea. 


\section{Handes}

Creative Planning dan Strategi Pengembangan Pesan Komunikasi Pemasaran

idea tersebut dibutuhkan riset kualitatif maupun kuantitatif untuk menemukan consumer insight yang akan diterjemahkan ke dalam strategi komunikasinya. Komunikasi Pemasaran bukan hanya persoalan konsistensi, tapi juga persoalan fleksibilitas dan kecerdasan membaca setiap titik proses. Proses pencarian idea komunikasi ini hanya dapat dilakukan melalui eksplorasi terhadap karakteristik khalayak sasaran baik secara kognitif (dipikiran/benak); konatif (perilaku beli/penggunaan), hingga afektif (preferensi). Berdasarkan insight yang kaya terhadap berbagai aspek karakteristik konsumen tersebut si marketer akan bisa mengolahnya menjadi sebuah konsep/ ide komunikasi yang betulbetul relevan dengan si target sasaran.

b. Strategi Kreatif

Di dalam merumuskan suatu pesan tentunya dibutuhkan strategi kreatif yang akan mendukung suatu pesan menjadi sesuai dengan tujuan periklanan suatu produk, sebab pesan merupakan hal yang sangat penting. Adapun tahap-tahap yang juga dilalui yaitu dengan melakukan tahap pembetukan evaluasi, seleksi, dan pelaksanaan pesan. Pembentukan pesan tentang suatu produk seperti yang telah dijelaskan di atas pada prinsipnya merupakan manfaat utama yang ditawarkan merk sebagai pengembangan konsep produk. Pesan iklan harus dapat disampaikan secara kreatif, bahkan kreatifitas ini lebih penting daripada jumlah uang atau budget yang dikeluarkan.Strategi kreatif adalah pilihan bentuk pesan yang dapat mencapai tujuan komunikasi maka perlu dipilih bentuk pesan yang sesuai. Pengertian strategi kreatif dapat memiliki arti yang berbeda-beda, karena startegi kreatif dapat dinilai dari sudut pandang siapa yang menglihatnya. Misalkan, seorang biasanya akan berfikir bahwa startegi keratif merupakan orientasi pemasaran yang diberikan kepada orang-orang kreatif sebagai pedoman dalam membuat suatu iklan. Nah, sedangkan bagi orang-orang kreatif sendiri sering dianggap sebagai hasil terjemahan dari berbagai informasi mengenai produk, pasar, dan konsumen sasaran kedalam sutau posisi tertentu didalam komunikasi yang kemudian dapat dipakai untuk merumuskan tujuan iklan.Setelah strategi kreatif ditetapkan, proses pengerjaan kreatif bisa dimulai yang mencakup pelaksanaan dan pengembangan konsep/ide yang dapat mengemu- 
kakan strategi dasar dalam bentuk komunikasi yang efektif termasuk pembuatan judul, perwajahan, naskah dalam bentuk file untuk iklan-iklan media cetak, tulisan untuk iklan radio, dan storyboard untuk iklan TV.

Menurut Gilson \& Berkman $(1986)^{25}$, perumusan strategi kreatif ada tiga tahap. 1) Mengumpulkan dan mempersiapkan informasi pemasaran yang tepat, yang menyangkut, rencana pemasaran dan komunikasi; hasil penelitian tentang konsumen sasaran; data tentang produk; pesaingan di pasar; dan rencana dasar strategi media (kapan dan dalam media apa yang iklan tersebut akan dimunculkan). 2) Orang kreatif menetapkan suatu posisi dalam penjualan serta menentukan tujuan iklan yang akan dihasilkan berdasarkan informasi yang diperoleh. 3) Presentasi didepan pengiklan/klien untuk memperoleh persetujuan sebelum rancangan iklan yang telah dibuat diproduksi dan dipublikasikan melalui media yang telah ditetapkan.

Wells, dkk mengatakan, "What the message will say and how

${ }^{25}$ Christopher Gilson \& Berkman (1986), dalam: Rhenald Kasali, Manajemen Periklanan Konsep dan Aplikasinya di Indonesia (Jakarta: Pustaka Utama Grafiti, 1992), hlm. 81-82. it will say. Should the message is hard-sell or soft-sell, informational or emotional. Should it build an image or attack a competitive position?". Setelah inti pesan (the big idea) telah ditemukan, perlu dipikirkan bagaimana strategi kreatif akan diterapkan, agar isi pesan tersebut dapat sampai dan diterima dengan tepat oleh sasaran, serta mampu mencapai tujuan komunikasi yang ditetapkan. Pada dasarnya dalam strategi kreatif atau pesan, dikembangkan dari dua focus utama yakni terfokus pada produk, atau terfokus pada sasaran. Apabila strategi terfokus pada produk, biasanya pemanfaatan kelebihankelebihan apa yang terkandung dalam suatu produk. Tetapi apabila fokus pada sasaran, maka strategi yang ditempuh adalah melalui halhal apa yang ada pada sasaran, seperti kebutuhan, keingingan, citra yang ada dan sejenisnya.Akan tetapi dalam mendesain strategi pesan kampanye, penyusunan pesan kampanye diperuntukkan bagi masing-masing publik yang menjadi khalayak sasaran. Wilson \& Ogden $(2008)^{26}$ mengemukakan bahwa

${ }^{26}$ Laurie J. Wilson, and Joseph D. Ogden, Strategic Communications Planning: For Effective 


\section{Handes}

Creative Planning dan Strategi Pengembangan Pesan Komunikasi Pemasaran

strategi perancangan pesan untuk sebuah kampanye terdiri dari dua bagian, yaitu Pesan Primer, "Sound bite statements that encompass what you are trying to motivate the public to do and include a short self-interst appeal" (dan Pesan sekunder, "Bulleted detail that include facts, testimonials, examples and all other informations or persuasive argumens that support a primary message".

c. Langkah Strategis dalam Pengembangan Pesan

Setidaknya ada tiga langkah dasar dalam mengembangkan strategi pesan kreatif: Pertama, menentukan tujuan komunikasi. Jenis dampak apa yang perlu dicapai pesan.Strategi dalam pengembangan pesan pada umumnya sudah menentukan tujuan komunikasi ataupun kegiatan kampanye dilakukan dalam jangka waktu tertentu yangdirancang sedemikian rupa, atraktif, kreatif, dan dinamis dalam rangka mempengaruhi pihak lain. Kegiatan ini seringkali memuncak pada event tertentu untuk menarik perhatian, dukungan, pemahaman, dan meningkatkan kesadaran sekaligus mempengaruhi masyarakat tentang suatu tema, isu, dan topik tertentu. Selanjutnya, proses kampanye melalui komunikasi ini antara lain dilakukan dengan penyebaran informasi, gagasan atau ide untuk membangun atau menciptakan kesadaran danpengertian. Kampanye dilakukan secara berencana, sistematis, memotivasi, dan dilakukan berulang-ulang secara kontinyu (repetition andcontinue).Pada langkah pertama pengembangan pesan biasanya diarahkan untuk menciptakan perubahan pada tataran pengetahuan atau kognitif. Pada tahap ini pengaruh yang diharapkan adalah munculnya kesadaran, berubahnya keyakinan atau meningkatnya pengetahuan khalayak tentang isu tertentu. Tahapan berikutnya diarahkan pada perubahan dalam ranah sikap atau attitude. Sasarannya adalah untuk memunculkan simpati, rasa suka, kepedulian atau keberpihakan khalayak pada isu-isu yang menjadi tema kampanye. Sementara pada tahap terakhir kegiatan kampanye ditujukan untuk mengubah perilaku khalayak secara konkrit dan terukur. Tahap ini menghendaki adanya tindakan tertentu yang dilakukan oleh sasaran kampanye. 


\begin{abstract}
Newsome, Scott, dan Turk $^{27}$ melalui lima elemen yang selalu ada dalam sebuah kampanye yang sukses. Elemen-elemen tersebut ialah: a) Education, sebuah kampanye seharusnya mencerahkan publicnya, memberitahu mereka sesuatu
\end{abstract} yang mereka belum tahu atau memberikan mereka perspektif yang berbeda atau cara pandang pada sesuatu yang telah mereka ketahui, atau mereka pikir telah mereka ketahui; b) Engineering, Yakni sarana atau kemudahan yang meyakinkan publik untuk melakukan apa yang kita ingin mereka lakukan; c) Enforcement, strategi ini yang mendorong seseorang melakukan apa yang dikampanyekan. Ia memberkan contoh kampanye penggunaan sabuk pengaman yang telah melalui fase education dan engineering tapi gagal memperoleh perubahan perilaku sampai hukum menyetujui denda bagi yang melanggar; d) Publik diyakinkan akan pesan nilai-nilai dari seruan kampanye. Upaya ini dibantu dengan reinforcement yakni upaya memperkuat pesan dengan mengulang pesan secara terus menerus sehingga publik tidak lupa,

27 Doug Newsome, Alan Scott, \& J.V. Turk, This is PR: The Realities of Public Relations (Belmont, CA: Wardsworth, 1993), hlm. 475-476 danjuga agar pesan tersebut dapat menjangkau anggota publik baru; e) Evaluation, evaluasi membantu organisasi mengetahui apakah ada perubahan dalam fokus kampanye atau tidak.

Kedua, Wawasan Pelanggan (Customer insight): Menemukan berlian dalam data. Wawasan pelanggan: sikap dan kepercayaan yang mempengaruhi perilaku pelanggan. Wawasan pelanggan adalah fondasi untuk memahami pelanggan. Tentang apa yang memicu orang membuat keputusan dan apa yang dibalik pikiran serta perasaan orangorang terhadap suatu produk atau jasa. Secara umum, dalam skala yang lebih besar, wawasan pelanggan ini didapat dari analisis database dan segmentasi pelanggan. Pada beberapa industri, ini bahkan diawali dengan membuat semacam profil personal pembeli (buyer personal). Tapi langkah dalam skala yang lebih kecil dan secara induktif bisa dilakukan. Sebagai contoh, sebuah website perusahaan, kita dapat mengumpulkan dan mempelajari data pelanggan dari bagian komentar, FAQ (Frequently Asked Questions), dan umpan balik. Untuk contoh offline, kita dapat mengumpulkan 


\section{Handes}

Creative Planning dan Strategi Pengembangan Pesan Komunikasi Pemasaran

wawasan ini dari lembar isian saran dan keluhan. Cara lain yang juga penting adalah percakapan yang terjadi di layanan pelanggan (customer service) baik lewat telepon, maupun pertemuan langsung. Ketika mengumpulkan datadata wawasan tersebut, Kita perlu memperhatikan bukan sekadar pada apa yang terang terang dan rinci, tapi terutama pada apa yang tidak tampak jelas, seperti ketertarikan, motif, dan hasrat seseorang. Tujuan dari semua upaya menelusuri wawasan pelanggan ini adalah untuk membuat informasi, pesan, cerita, atau konten yang bisa ditemukan, dikonsumsi, menimbulkan keterlibatan, dan akhirnya membuat orang melakukan pembelian. Misalnya rokok Marlboro. Wawasan bahwa pria muda dan setengah baya berkhayal tentang kebebasan \& macho kemerdekaan koboi. Ini memungkinkan pria untuk melarikan diri ke dalam fantasi ini ${ }^{28}$.

\section{Ketiga, Memilih Strategi}

Menjual. Dalam menentukan isi pesan yang terbaik, manajemen dapat memilih daya tarik, tema, ide, atau usulan-usulan penjualan yang

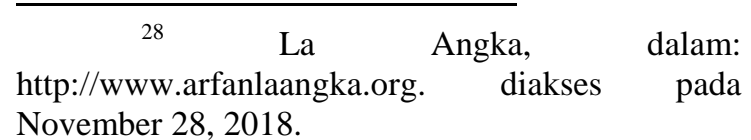

unik.Menurut Kotler $(2002)^{29}$ ada tiga jenis daya Tarik, yaitu: 1) daya Tarik Rasional. Daya tarik rasional menunjukkan minat seseorang, menunjukkan bahwa produk tersebut akan menghasilkan manfaat seperti yang dikatakannya; 2) Daya Tarik Emosional. Daya tarik emosional mencoba membangkitkan emosi positif atau negatif, yang akan memotivasi pembelian; 3) Daya Tarik Moral. Daya tarik moral diarahkan padaperasaan audiens tentang apa yang benar dan tepat. Dayatarik moral sering digunakan untuk mendorong orangmendukung masalah-maslah sosial.

\section{KESIMPULAN}

Perencanaan kreatif disusun sebagai acuan dalam pelaksanaan kampanye komunikasi pemasaran. Dalam sebuah penyelenggaraan kampanye, perencanaan kreatif menjadi penting untuk menghasilkan kreativitas pemasaran yang berbeda, unik dan menarik dibandingkan pesaing. Perencanaan kreatif disusun sebagai acuan dalam pelaksanaan kampanye komunikasi pemasaran. Dalam sebuah penyelenggaraan kampanye, perencanaan kreatif menjadi penting untuk

${ }^{29}$ Philip Kotler, Manajemen Pemasaran, Edisi Millenium, Jilid 2, (Jakarta. PT Prenhallindo, (2002), hlm. 633. 
menghasilkan kreativitas pemasaran yang berbeda, unik dan menarik dibandingkan pesaing. Maka dari itu strategi kreatif dibutuhkan dalam menyusun perencanaan kreatif.

Sedangkan strategi pengembangan pesan dapat diartikan sebagai proses menemukan cara untuk mempengaruhi publik atau sasaran tertentu dengan cara membujuk atau persuasif dan memotivasi publik untuk berpartisipasi, sehingga pesan diharapkan dapat menciptakan efek tertentu seperti yang direncanakan sesuai dengan tema spesifik. Pengembangan pesan berawal dari suatu gagasan (big idea) untuk menyatakan maksud tertentu sesuai dengan kebutuhan dan manfaat yang kemudian di konstruksi menjadi bentuk pesan-pesan yang disampaikan kepada khalayak sasaran. Tujuan pengembangan pesan hanya dapat dicapai apabila khalayak memahami pesan-pesan tersebut. Strategi pengembangan pesan menjadi fokus penting dalam tahapan perencanaan kreatif yang kemudian tertuang dalam turunan perencanaan pesan pada kegiatan kampanye komunikasi pemasaran. Pesan dapat disampaikan panjang lebar, namun yang perlu diperhatikan dan diarahkan adalah tujuan akhir dari pesan itu sendiri. Dalam strategi pengembangan pesan terdapat dua aspek penting, yaitu isi pesan (the content of message) dan lambang/ symbol untuk mengekspresikannya. Simbol pada komunikasi umumnya adalah bahasa yang dapat mengungkapkan pikiran dan perasaan, fakta dan opini hal yang kongkrit dan abstrak, pengalaman yang sudah lalu dan yang akan datang dan sehingga pesan dapat berkembang).

\section{DAFTAR PUSTAKA}

Batey, Ian. (2003). Asian Branding: A Great Way to Fly. Jakarta: Bhuana Ilmu Populer.

Doug Newsome, Alan Scott, \& J.V. Turk, (1993). This is PR: The Realities of Public Relations. Belmont, CA: Wardsworth.

Dru, Jean-Marie. (2007). How Disruption Brought Order, The Story of a Winning Strategy in the World of Advertising. USA: Palgrave Macmillan dikutip dari Kurniasari, Dian. (2013). As Big as Idea. https://www.kompasiana. com/ dian_kur/552a42f8f17e61b9 71d623b4/as-big-as-idea.

Durianto, Darmadi, dkk. (2003). Invasi Pasar dengan Iklan yang Efektif. Gramedia. Jakarta.

Effendy, Onong Uchjana. (1989). Kamus Komunikasi. Bandung. PT. Mandar Maju.

. (2001). Ilmu Komunikasi Teori dan Praktek. Bandung. PT.Remaja Rosdakarya.

Hakim, Budiman. (2005). Lanturan Tapi Relevan, Cetakan I, Penerbit Galang Press (Anggota IKAPI).

Harold W. Berkman, Christopher C. Gilson. (1986). Consumer Behavior: Concepts and Strategies. Kent Publishing Company. 
https://www.coursehero.com/file/pi43omj/ 2-Memposisikan-Bertujuanuntuk-memposisikan-produkdengan-membedakan-diri/

http://www.arfanlaangka.org.

Kenneth Roman, Jane Maas, Martin Nisenholtz. (2005). How to Advertise: Membangun Merk dan Bisnis dalam Dunia Pemasaran Baru. Jakarta. PT. Elex Media Komputindo.

Kasali, Rhenald. (1992). Manajemen Periklanan Konsep dan aplikasinya Di Indonesia. Jakarta. Pustaka Utama Grafiti.

Kotler, Philip. (2002). Manajemen Pemasaran, Edisi Millenium, Jilid 2, Jakarta. PT Prenhallindo.

Laurie J. Wilson, Joseph D. Ogden. (2008). Strategic Communications Planning: For Effective Public Relations and Marketing. Front Cover. Kendall/Hunt Pub.

Larry A. Samovar,\&Richard E. Porter. (1994). Intercultural Communication: A Reader: A Reader. Limited preview.

Madjadikara, Agus S. (2004). Bagaimana Biro Iklan Memproduksi Iklan. PT. Gramedia Pustaka. Jakarta.

Mulyana, Deddy. (2000). Ilmu Komunikasi Suatu Pengantar. Bandung. PT. Remaja Rosdakarya.

Richard West dan Lynn H. Turner. (2010). Introducing Communication Theory, 4th ed. McGraw Hill. New York.

Roman, Kenneth, Jane, Maas. \& Martin, Nisenholtz. (2003). How to Advertise: Membangun Merek dan Bisnis Dalam Dunia Pemasaran Baru. Alex Media Komputindo. Jakarta.

Roman, Kenerth. Jane Maas., \& Martin Nisenholtz. (2005). How to
Advertise: Membangun Merek dan Bisnis dalam Dunia Pemasaran Baru. Jakarta. PT. Elex Media Komputindo.

Suryanto, Muhammad.(2004). Aplikasi Desain Grafis Untuk Periklanan. Andi. Yogyakarta.

Suyanto, Muhammad. (2005). Strategi Perancangan Iklan Televisi Perusahaan Top Dunia. Yogyakarta. Penerbit Andi Offset.

Solihin (2015).Terpaan Iklan Mendorong Gaya Hidup Konsumtif Masyarakat Urban. Jurnal Ilmu Politik dan Komunikasi Volume V/No. 2/Desember.

Smith, D. Ronald. (2005). Strategic Planning For Public Relations. Second Edition. Lawrence Erlbaum Associates Publisher. London.

Surtherland, Max. \& Alice, K. Silvester. (2005).Advertising and Mind of the Consumer, Jakarta.Penerbit PPM.

Suyanto, M. (2004). Aplikasi Desain Grafis Untuk Periklanan. Yogyakarta. Penerbit Andi offset. . (2005). Strategi Perancangan Iklan Televisi Perusahaan Top Dunia. Yogyakarta. Penerbit Andi Offset.

Siahaan, S.M. (1991). Komunikasi Pemahaman dan Penerapan. Jakarta. PT. BPK Gunung Mulia.

Widjaja, A.W dan M.Arisyk Wahab, (2000). Strategi Public Relations. Jakarta. PT. Raja Grafindo Persada.

Widyastuti, Sri. (2017). Manajemen Komunikasi Pemasaran Terpadu. Srengseng Sawah, Jagakarsa Jakarta Selatan.FEB-UP Press. 